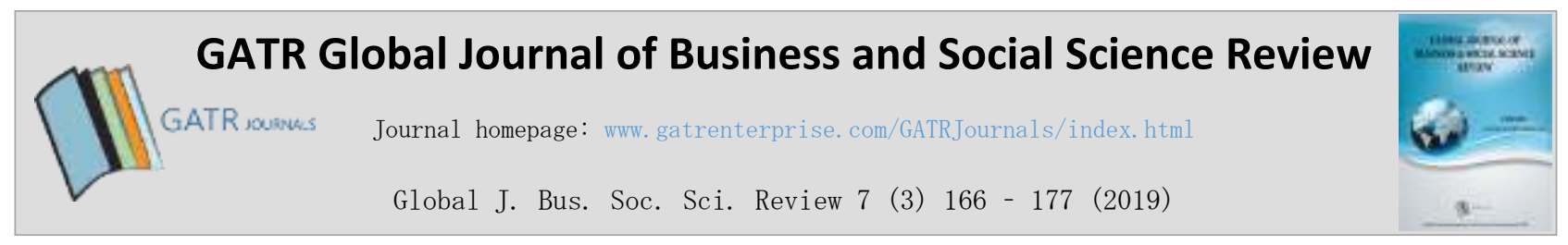

\title{
Identifying Aspects toward EWOM Credibility and Source of Trustworthiness
}

\author{
Ni Made Dhiar Wulan Vitaloka ${ }^{1}$, Yeshika Alversia ${ }^{2 *}$ \\ ${ }^{12}$ Faculty of Economics and Business Universitas Indonesia, Jakarta, Indonesia
}

\begin{abstract}
Objective - Nowadays, people became conscious of their outward appearance and use make-up and skincare to enhance their appearance. The trends in personal care are influenced by the advancement of social media. People use social media to share their opinion, thoughts, and experience about personal care. This study is purposed to analyze aspects such as homophily, authority, and interestingness towards purchase intention as independent aspects with EWOM credibility and source of trustworthiness as a mediating variable.

Methodology/Technique - This study uses purposive sampling with 485 respondent samples from Indonesia and uses a method of scaling and structural equation model to see the relationship between variables.

Finding and Novelty - The result of this research implies that homophily, authority, and interestingness has a significant effect on the source of trustworthiness. Furthermore, authority and source of trustworthiness has a significant impact on EWOM credibility. EWOM credibility is having a substantial impact on purchase intention. It is also found that homophily, authority, and interestingness strengthen EWOM credibility through a source of trustworthiness. This finding concludes that the source of trustworthiness works to strengthen independent aspects of EWOM credibility rather than depending on EWOM credibility itself.
\end{abstract}

Type of Paper: Empirical.

Keywords: Homophily; Authority; Interestingness; Purchase Intention; Source of Trustworthiness; EWOM credibility; Personal care.

Reference to this paper should be made as follows: Vitaloka, N.M.D.W; Alversia Y. (2019). Identifying Aspects toward EWOM Credibility and Source of Trustworthiness, Global J. Bus. Soc. Sci. Review 7 (3): 166 - 177. https://doi.org/10.35609/gjbssr.2019.7.3(1)

JEL Classification: M31, M39.

\section{Introduction}

Indonesia has the largest economy in Southeast Asia with a population of 250 million and a GDP of US $\$ 888.5$ billion. With this development, analysts forecast that in the next 15 years, Indonesia will become one of the top five markets for cosmetics. The middle-class segment has grown due to an increase in minimum wages and employment level.

\footnotetext{
* Paper Info: Revised: July 10, 2019

Accepted: September 23, 2019

* Corresponding author: Yeshika Alversia

E-mail: yeshika@ui.ac.id

Affiliation: Faculty of Economics and Business Universitas Indonesia, Jakarta, Indonesia
} 
The increase in minimum wages has influenced their budget for consumer products, specifically on personal care and cosmetics products. Fast Moving Consumer Goods companies such as L'Oreal and Procter and Gamble dominate the industry with 50\% market share. However, there is a significant growth in demand for premium brands and imported products. The number of imported products for personal care products has exceeded other imported products (Industry, 2017).

In Indonesia, people became conscious in fashion and image. Make-up and skincare has become a priority for women. They take outward appearance as the first impression (Moslehpour \& Wong, 2017). The trend of image and media is affected by the advancement of social media, which Indonesia is actively using to share their opinions, thoughts, and experiences, about personal care. Their review or word-of-mouth will influence consumer's perspective before purchasing a product (Ministry of Trade, 2017). Word-of-mouth embodies a basic form of communication in terms of altering the attitudes of consumers. The attitude happens because the interaction between 2 customers is convincing and compelling. Companies realized the relevance and they are looking forward to managing online reviews while maintaining the credibility of information and providing the influencer with incentives (Reimer \& Benkenstein, 2018) Successful companies are using social media and platforms to retain their image and interact with consumers (Chakraborty, 2017)

The growing number of people looking for information before purchasing has reassured customers to confide their opinions in an online review. The number of online reviews is growing along with a preferences for products (Hu \& Kim, 2018). When customers are looking for a product review, they tend to look for a review from a verified source. The consumer can read the review through a personal blog, online forum, or official website (Shang, Wu, \& Sie, 2017). Consumers are also willing to learn and communicate with brands through specific channels. It is reported that $67 \%$ have watched videos from a brand on YouTube, and $70 \%$ have read a blog platform from a corporate brand (Vanmeter, Syrdal, Powell-Mantel, Grisaffe, \& Nesson, 2018). This platform provides an opportunity to companies to the degree that they can learn about consumers' behavior and keep engaging with them (Moslehpour \& Wong, 2017)

One company that provides a platform for personal care is Femaledaily.com. Femaledaily.com is an independent website focusing on woman's wellbeing. Femaledaily.com has a feature for review where a customer can write a review and share it (Wanita, 2017). The website that has featured reviews became a vital source for electronic word-of-mouth or online reviews that are important for the consumer. If a trusted online community has written an online review and has an independent reviewer, then the consumer will trust the report and will consider it before purchasing products (Shamhuyenhanzva, Tonder, Roberts-Lombard, \& Hemsworth, 2016).

Word-of-mouth has been one of the most exciting topics to arise (Shang, Wu, \& $\mathrm{Li}, 2017$ ). However, the characteristics of the individual might be essential to explain the behavior of word-of-mouth (Hu \& Kim, 2018) Demographic criteria such as gender, income, and age have been reported to affect word- of-mouth. There is also a connection among personality traits with word-of-mouth, which is more compelling compared to demographics ( $\mathrm{Hu} \& \mathrm{Kim}, 2018)$. In practice, the number of studies on the relationship between personality, word-of-mouth, and purchase intention is limited (Tien, Amaya Rivas, \& Liao, 2018). Hence, this research is purposed to explore beyond word-of-mouth with a focus on factors that affect consumers in reading the reviews and what leads them to purchase intention.

Numerous factors may affect the consumer in reading reviews (Hussain, Ahmed, Jafar, Rabnawaz, \& Jianzhou, 2017). If the consumer sees that a trusted source with high credibility wrote a review, then it is easier for the consumer to accept the review (Shamhuyenhanzva et al., 2016). Three factors affect the credibility of the review: interestingness, homophily, and authority. The discussion explains interestingness as to how consumers become fascinated with particular content. The more consumer engages in second thoughts, the more natural it is for the consumer to accept it (Shamhuyenhanzva et al., 2016). Besides interestingness, another factor that affects credibility is homophily. Homophily is a tendency of consumers to build relationship with other individuals who share the same characteristics and attributes. These people 
prefer to communicate with other individuals who share mutual perspectives. This factor tends to influence people through reviews (Shamhuyenhanzva et al., 2016). The last factor is authority, or the level of consumer that believes EWOM will affect the consumer's reasons for taking action (Shamhuyenhanzva et al., 2016; Shang, $\mathrm{Wu}, \& \mathrm{Li}, 2017)$.

The effectiveness of information and credibility is related to the source of information. If the source can be trusted, then the information can be considered credible (Shamhuyenhanzva et al., 2016). By this finding, the source of trustworthiness can be used as the mediator variable between 3 independent variables and EWOM credibility. The researcher finds the opportunity to explore this research by using the personal care industry as the topic of this research and investigating the relationship of relevance theory and the proposed model. As explained before, the industry of personal care in Indonesia has expanded, and women have become aware of their first appearance (Industry, 2017; Ministry of Trade, 2017). Femaledaily.com platform was chosen as the subject by reason of being the first online platform for women in Indonesia (Wanita, 2017) .It is expected that credibility will lead consumers to purchase intention (Campbell \& Fairhurst, 2016; Shamhuyenhanzva et al., 2016; Vahdati, Hadi, \& Nejad, 2016). Hence, this research uses purchase intention as the final variable. This research is purposed to help companies and brands to learn about consumers' attitudes and retain their engagement in the future.

\section{Literature Review}

Word-of-mouth (WOM) is exchanging information between the individual that desires to communicate about their experiences related to brands and products that is informal and not related to commercial on the Internet (Beneke et al., 2016; Hidayanto, Ovirza, Anggia, Ayuning, \& Phusavat, 2017). Technology has changed the way WOM is delivered (Shamhuyenhanzva et al., 2016). By the advancement of technology, now people have access to read and share electronic word-of-mouth (EWOM) on the Internet (Shamhuyenhanzva et al., 2016). People consider EWOM as a valuable resource that provides insight for a potential consumer to see the quality of a product or service. However, there is much information provided on the Internet that the consumer prefers to see the rating before reading the context in detail. They also check for credibility before reading the information further (Yang, Park, \& Hu, 2018).

EWOM credibility is the level of consumer confidence in the product, reviews, and recommendations that are considered correct and based on reliable information. The higher the credibility of EWOM, the greater the adoption of second thoughts (Shamhuyenhanzva et al., 2016). There are many factors that can affect the credibility of EWOM itself. In 2016, the 3 factors of authority, homophily, and interestingness have proven to leverage the credibility of EWOM, which is also influenced by the source who provides the messages (Shamhuyenhanzva et al., 2016).

Homophily is the motivation of the individual to build a relationship with other individuals who share the same attributes and characteristics like age, gender, education, and social status. As a social creature, the individual develops a relationship with others with whom they share traits (Shamhuyenhanzva et al., 2016; Won \& Lee, 2016). This theory was introduced by Lazarsfeld in 1954 as psychological theory (Pauwels, Aksehirli, \& Lackman, 2016). This factor plays a vital role in affecting the credibility of reviews on the Internet. When an individual evaluates their purchase, they are not only considering the price or quality but also the input from other consumers to make sure that the decision is the right choice (Shamhuyenhanzva et al., 2016; Shang, Wu, \& Sie, 2017).

Authority was first introduced by Wilson in 1983 to explain the people behind the role. He assumes that people know something based on 2 factors: from their own experience and from others' experience (Jafar, 2011). The term authority was used to explain the level of consumer confidence about the review of a product that makes an impact on them (Kim \& Hanssens, 2017; Shamhuyenhanzva et al., 2016).

Interestingness means the ability of information offered by EWOM to attract the attention of visitors and recipients. Developments in technology and communication give visitors much information related to products such as promotions (Shamhuyenhanzva et al., 2016). With the development of technology and

Global J. Bus. Soc. Sci. Review 7 (3) $166-177$ (2019) 
communication, visitors have access to information related to a product such as promotion and social media content. The more they are interested, the more they spend their time on websites (Darsono \& Huarng, 2015).

Source of trustworthiness represents the level of consumer confidence that the information provided is honest and validated information (Shamhuyenhanzva et al., 2016). Readers will trust the information if the source has no other motivation. People will trust information if the source were coming from their own experience rather than from a company. A further study conducted by Nielsen also confirmed that people's own opinions are the most trusted source. Purchase intention was explained as the desire of consumers to make a purchase that suits their needs (Vahdati et al., 2016). Various factors have influenced the implementation of the theory of purchase intention such as how much consumers want to buy products, how much pressure there is from society to buy products, and what value is received by consumers $(\mathrm{Ng}, \mathrm{Law}, \&$ Zhang, 2018) Purchase intention explains the needs of consumers to make purchases that suit their needs (Vahdati et al., 2016). The implementation of purchase intention is influenced by many factors such as pressure from society and the value consumers will get (Martins, Costa, Oliveira, Gonçalves, \& Branco, 2019).

Based on theory, it is hypothesised in this study that:

H1: Homophily has a positive influence on Source of Trustworthiness

H2: Authority has a positive influence on Source of Trustworthiness

H3: Interestingness has a positive influence on Source of Trustworthiness

H4: Homophily has a positive influence on EWOM credibility

H5: Authority has a positive influence on EWOM credibility

H6: Interestingness has a positive influence on EWOM credibility

H7: Source of Trustworthiness has a positive influence on EWOM credibility

H8: EWOM credibility has a positive influence on Purchase Intention

\section{Research Methodology}

\subsection{Data and sample selection}

This research is using a sample that consists of women and men ranging from 17 to 60 years old who live in Indonesia. The main target of this research is women. However, men can also be included as targets as there si an increasing number of men who use personal care (Industry, 2017; Ministry of Trade, 2017) . This research is using purposing sampling as it only selects targets who had watched or read Femaledaily.com because they might be the one to present an in-depth knowledge of personal care products review. The number of the sample was defined using the rule of thumb. Based on the number of variable times ten, the minimum sample required for this research is 140 people.

\subsection{Research Model}

This research is using a structured self-administered questionnaire. The questionnaire is using a 6-points Likert scale from strongly disagree (score 1) to strongly agree (score 6). This research will use two applications such as IBM SPSS 23 to test the validity and reliability, and IBM SEM (Structural Equation Modelling) AMOS to know the relationships among variables and the contribution for each variable. Values for all variables will be analyzed at the level of significance of $p<0.05$. This research will use the confirmatory factor analysis model to analyze validity. 


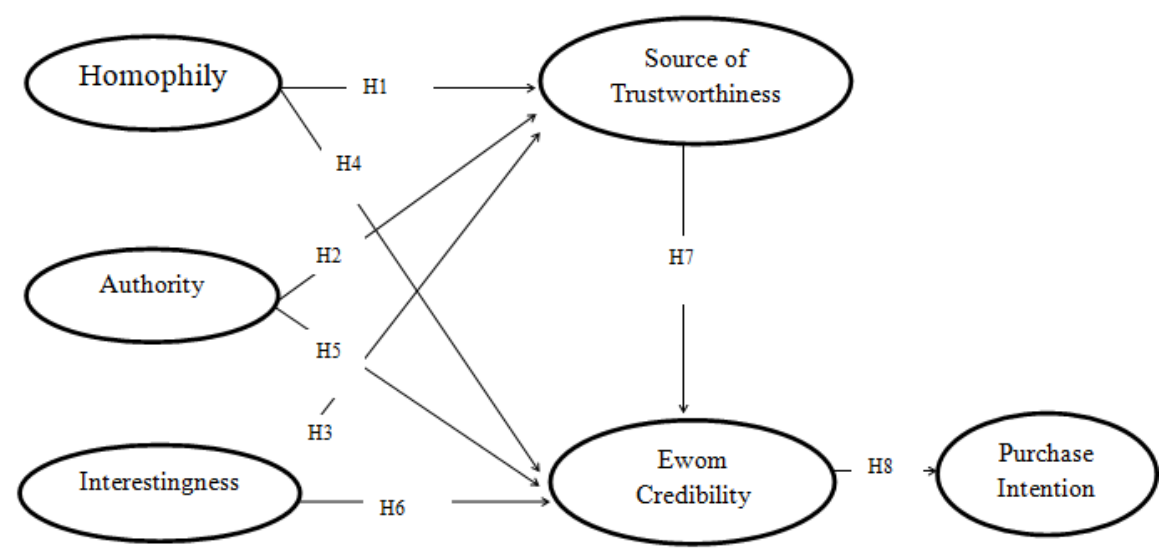

Figure 1. Research Model

\section{Results}

From a total of 500 participants, 485 respondents are eligible to continue for further questionnaires, while 15 respondents were discarded because they didn't meet the requirements. Therefore, the final sample for this research was 485 respondents.

\subsection{Preliminary Analysis}

This research is using Bartlett test and Kaiser-Meyer-Olkin test to assess adequacy of sampling. The data has overall KMO statistic of 0.830 , which exceeds the minimum value of 0.60 . The data also shows significance with all variables having significant effect $<0.05$. Therefore, the data can be used for further analysis.

\subsection{Respondent Profile}

After the preliminary analysis is conducted, 485 respondents will proceed to the next step of the questionnaire. Based on the results, it can be concluded that $95 \%$ of respondents are women who had watched or read Femaledaily.com. The majority of the respondents is between 18-30 years old or included as a millennial club. Respondents also have a minimum high school or bachelor's degree, which means that they are highly educated. However, their income is lower than the Rp. 3.000.000/month. Most of the respondents reside outside Jakarta.

Table 1 Respondent Profile

\begin{tabular}{|c|c|c|c|}
\hline $\begin{array}{l}\text { Demographic } \\
\text { Characteristic }\end{array}$ & Category & \multicolumn{2}{|c|}{$\begin{array}{l}\text { Respondents } \\
\qquad(\mathrm{N}=\mathbf{4 8 5})\end{array}$} \\
\hline \multirow{2}{*}{ Gender } & Men & 22 & $5 \%$ \\
\hline & Woman & 463 & $95 \%$ \\
\hline \multirow{5}{*}{ Age } & 18 - 30 Years Old & 419 & $86 \%$ \\
\hline & $31-40$ Years Old & 50 & $10 \%$ \\
\hline & 41 - 50 Years Old & 14 & $3 \%$ \\
\hline & $51-60$ Years old & 0 & 0 \\
\hline & 61 Years old & 0 & 0 \\
\hline Education & Highschool & 107 & $22 \%$ \\
\hline
\end{tabular}

Global J. Bus. Soc. Sci. Review 7 (3) 166 -177 (2019) 


\begin{tabular}{|l|l|l|l|}
\hline $\begin{array}{c}\text { Demographic } \\
\text { Characteristic }\end{array}$ & \multicolumn{1}{|c|}{ Category } & \multicolumn{2}{c|}{$\begin{array}{c}\text { Respondents } \\
\text { (N=485) }\end{array}$} \\
\hline \multirow{5}{*}{ Income } & Diploma degree & 43 & $9 \%$ \\
\cline { 2 - 4 } & Bachelor degree & 115 & $24 \%$ \\
\cline { 2 - 4 } & Master Degree & 20 & $4 \%$ \\
\cline { 2 - 4 } & Postgraduate & 0 & 0 \\
\hline \multirow{5}{*}{ Domicile } & $<3.000 .000$ & 143 & $29 \%$ \\
\cline { 2 - 4 } & Rp. 3.000.000 - Rp. 6.000.000 & 73 & $15 \%$ \\
\cline { 2 - 4 } & Rp 6.000.000 - Rp. 10.000.000 & 49 & $10 \%$ \\
\cline { 2 - 4 } & $>$ Rp. 10.000.0000 & 20 & $4 \%$ \\
\hline & Jakarta & 40 & $8 \%$ \\
\cline { 2 - 4 } & Bogor & 11 & $2 \%$ \\
\cline { 2 - 4 } & Depok & 12 & $2 \%$ \\
\cline { 2 - 4 } & Tangerang & 22 & $5 \%$ \\
\cline { 2 - 4 } & Bekasi & 192 & $40 \%$ \\
\cline { 2 - 4 } & Other area & & \\
\hline
\end{tabular}

\subsection{Validity and Reliability}

Table 2 shows the standard loading factor (SLF), CR, AVE, and Cronbach alpha. Based on the results, it can be concluded that all criteria pass the minimum cut-off value and have met the validity and reliability.

Table 2 Validity and Reliability

\begin{tabular}{|c|c|c|c|c|c|}
\hline \multicolumn{2}{|l|}{ Item } & SLF & CR & AVE & $\begin{array}{l}\text { Cronbach's } \\
\text { Alpha }\end{array}$ \\
\hline \multirow{4}{*}{ Homophily } & $\begin{array}{l}\text { H1: I feel accepted as part of the } \\
\text { community when reading } \\
\text { Femaledaily.com }\end{array}$ & 0.807 & \multirow{4}{*}{0.8} & \multirow{4}{*}{0.70} & \multirow{4}{*}{0.95} \\
\hline & $\begin{array}{l}\mathrm{H} 2 \text { : I feel that Femaledaily.com is } \\
\text { in accordance with my interests }\end{array}$ & 0.892 & & & \\
\hline & $\begin{array}{l}\text { H3: I am interested in discussing } \\
\text { product reviews in this community }\end{array}$ & 0.819 & & & \\
\hline & $\begin{array}{l}\text { H4: I am interested in connecting } \\
\text { with people in this community }\end{array}$ & 0.861 & & & \\
\hline \multirow{3}{*}{ Authority } & $\begin{array}{l}\text { A1: Femaledaily.com } \\
\text { recommendations often affect me to } \\
\text { try personal-care products }\end{array}$ & 0.912 & \multirow{3}{*}{0.75} & \multirow{3}{*}{0.859} & \multirow{3}{*}{0.91} \\
\hline & $\begin{array}{l}\text { A2: Products that have been } \\
\text { reviewed by Femaledaily.com made } \\
\text { me motivated to try them }\end{array}$ & 0.941 & & & \\
\hline & $\begin{array}{l}\text { A3: The Femaledaily.com website } \\
\text { has influenced me to buy personal- } \\
\text { care products }\end{array}$ & 0.907 & & & \\
\hline
\end{tabular}




\begin{tabular}{|c|c|c|c|c|c|}
\hline \multicolumn{2}{|l|}{ Item } & SLF & CR & AVE & $\begin{array}{l}\text { Cronbach's } \\
\text { Alpha }\end{array}$ \\
\hline \multirow{3}{*}{ Interestingness } & $\begin{array}{l}\text { I1: I am more interested in reading } \\
\text { personal care products review that } \\
\text { have a positive rating at } \\
\text { Femaledaily.com }\end{array}$ & 0.857 & \multirow{3}{*}{0.75} & \multirow{3}{*}{0.775} & \multirow{3}{*}{0.91} \\
\hline & $\begin{array}{l}\text { I2: I am more interested in reading } \\
\text { reviews of personal care products } \\
\text { with a positive rating at } \\
\text { Femaledaily.com }\end{array}$ & 0.911 & & & \\
\hline & $\begin{array}{l}\text { I3: I am more interested in positive } \\
\text { reviews from other readers about } \\
\text { products at Femaledaily.com }\end{array}$ & 0.866 & & & \\
\hline \multirow{4}{*}{$\begin{array}{l}\text { Source of } \\
\text { Trustworthiness }\end{array}$} & $\begin{array}{l}\text { SOT1: I trust personal care product } \\
\text { reviews at Femaledaily.com }\end{array}$ & 0.909 & \multirow{4}{*}{0.79} & \multirow{4}{*}{0.66} & \multirow{4}{*}{0.864} \\
\hline & $\begin{array}{l}\text { SOT2: I trust information about } \\
\text { personal care provided by } \\
\text { consumers at Femaledaily.com }\end{array}$ & 0.832 & & & \\
\hline & $\begin{array}{l}\text { SOT3: I trust information that is } \\
\text { sponsored by personal care brands } \\
\text { in the form of articles or videos at } \\
\text { Femaledaily.com }\end{array}$ & 0.672 & & & \\
\hline & $\begin{array}{l}\text { SOT4: I trust reviews from editors } \\
\text { in the form of articles / reviews / } \\
\text { videos at Femaledaily.com }\end{array}$ & 0.835 & & & \\
\hline \multirow{3}{*}{ EWOM } & $\begin{array}{l}\text { EWOM1: Reviews about personal } \\
\text { care at Femaledaily.com are reliable }\end{array}$ & 0.884 & \multirow{3}{*}{0.74} & \multirow{3}{*}{0.63} & \multirow{3}{*}{0.868} \\
\hline & $\begin{array}{l}\text { EWOM2: Reviews of personal care } \\
\text { products at Femaledaily.com.com } \\
\text { written by trusted customers }\end{array}$ & 0.798 & & & \\
\hline & $\begin{array}{l}\text { EWOM3: Reviews of personal care } \\
\text { products at Femaledaily.com.com } \\
\text { are written by experienced } \\
\text { customers }\end{array}$ & 0.694 & & & \\
\hline \multirow{3}{*}{$\begin{array}{l}\text { Purchase } \\
\text { Intention }\end{array}$} & $\begin{array}{l}\text { PI1: I am interested in buying } \\
\text { personal care products after I see } \\
\text { the reviews } \\
\text { Femaledaily.com.com }\end{array}$ & 0.894 & \multirow{3}{*}{0.9} & \multirow{3}{*}{0.60} & \multirow{3}{*}{0.813} \\
\hline & $\begin{array}{l}\text { PI2: I am interested in buying } \\
\text { personal care products because the } \\
\text { Femaledaily.com recommends the } \\
\text { product }\end{array}$ & 0.849 & & & \\
\hline & $\begin{array}{l}\text { PI3: I will buy personal care } \\
\text { products that have a high rating or } \\
\text { positive reviews at } \\
\text { Femaledaily.com.com }\end{array}$ & 0.795 & & & \\
\hline
\end{tabular}




\begin{tabular}{|l|l|l|l|l|l|}
\hline \multicolumn{2}{|l|}{ Item } & SLF & CR & AVE & $\begin{array}{l}\text { Cronbach's } \\
\text { Alpha }\end{array}$ \\
\hline \multicolumn{1}{|l|}{$\begin{array}{l}\text { PI4: I will buy personal care } \\
\text { products that I read on } \\
\text { Femaledaily.com.com when I need } \\
\text { the product }\end{array}$} & 0.778 & & \\
\hline
\end{tabular}

Validity and reliability test were conducted in order to ensure that the data measured is consistent with constructs theory. Based on the data, it is concluded that all construct variables have passed minimum Cronbach alpha value of 0.6. After the reliability test, CFA was conducted for validity test. All factors have significant effect with $(\mathrm{p}<0.01)$ and indicated as valid. Measurement models were respecified 4 times before reaching a good fit. The results of the measurement model after respecification showed a good fit (CFI: 0.956, IFI: 0.956, NFI: 0.938 RMSEA: 0.069).

\subsection{Hypothesis Testing}

After reliability and model fit test, the research model can now be examined. Based on the data, not all hypotheses were supported. Hypothesis 4 and 6 were not supported, while the other hypotheses were supported with p-value below 0.001 and T-value exceeding 1.645 .

Table 3 Hypothesis Testing

\begin{tabular}{|c|c|c|c|c|}
\hline Hypothesis & SLF & T-value & $\mathbf{P}$ & Conclusion \\
\hline $\begin{array}{l}\text { H1: Homophily has positive impact } \\
\text { towards Source of Trustworthiness }\end{array}$ & 0.268 & 4.956 & $<0.001$ & $\begin{array}{l}\text { Hypothesis } \\
\text { supported }\end{array}$ \\
\hline $\begin{array}{l}\text { H2: Authority has positive impact } \\
\text { Source of Trustworthiness }\end{array}$ & 0.333 & 5.817 & $<0.001$ & $\begin{array}{l}\text { Hypothesis } \\
\text { supported }\end{array}$ \\
\hline $\begin{array}{ll}\text { H3: Interestingness } & \text { has positive } \\
\text { impact towards } & \text { Source of } \\
\text { Trustworthiness } & \end{array}$ & 0.318 & 6.472 & $<0.001$ & $\begin{array}{l}\text { Hypothesis } \\
\text { supported }\end{array}$ \\
\hline $\begin{array}{l}\text { H4: Homophily has positive impact } \\
\text { towards EWOM Credibility }\end{array}$ & 0.053 & 1.280 & 0.201 & $\begin{array}{l}\text { Hypothesis is not } \\
\text { supported }\end{array}$ \\
\hline $\begin{array}{l}\text { H5: Authority has positive impact } \\
\text { towards EWOM Credibility }\end{array}$ & 0.162 & 3.660 & $<0.001$ & $\begin{array}{l}\text { Hypothesis } \\
\text { supported }\end{array}$ \\
\hline $\begin{array}{l}\text { H6: Interestingness has positive } \\
\text { impact towards EWOM Credibilitity }\end{array}$ & 0.056 & 1.452 & 0.146 & $\begin{array}{l}\text { Hypothesis is not } \\
\text { supported }\end{array}$ \\
\hline $\begin{array}{l}\text { H7: Source of Trustworthiness has } \\
\text { positive impact towards EWOM } \\
\text { Credibility }\end{array}$ & 0.764 & 14.633 & $<0.001$ & $\begin{array}{l}\text { Hypothesis } \\
\text { supported }\end{array}$ \\
\hline $\begin{array}{l}\text { H8: EWOM Credibility has positive } \\
\text { impact towards Purchase Intention }\end{array}$ & 0.861 & 24.591 & $<0.001$ & $\begin{array}{l}\text { Hypothesis } \\
\text { supported }\end{array}$ \\
\hline
\end{tabular}

Based on the data, it can be concluded that Homophily, Authority, and Interestingness have positive effects on Source of Trustworthiness; Authority and Source of Trustworthiness have positive effects on EWOM Credibility, and EWOM Credibility has a positive effect on Purchase Intention. However, there is no positive effect of Homophily and Interestingness toward EWOM Credibility.

\section{Discussion}

Based on Table 3, it can be seen that Homophily has a positive effect on Source of Trustworthiness. This can be seen from t-value of 4.956 and significant $\mathrm{P}$ value, which is below 0.001 . This result is similar to

Global J. Bus. Soc. Sci. Review 7 (3) $166-177$ (2019) 
research conducted by Shamhuyenhanzva et al. (2016). This explained that the respondent feels that Femaledaily.com has content that meets their interest, and respondents are motivated to communicate with people through this website. Based on this, it can be concluded that Homophily or motivation from the reader to interact with people who share similar characteristics can be a trusted source for a consumer to gain valid and accurate information.

Authority also has a positive effect on Source of Trustworthiness with t-value 5.817 and significant value below 0.001. This explains that reviews of products and recommendations from Femaledaily.com can motivate the consumer to try personal care. Based on this result, it can be concluded that consumers will trust personal care reviews if they are getting information from a trusted source.

Interestingness affects Source of Trustworthiness significantly. This can be seen from significant value and t-value, which meets the requirements of this research. Based on this result, it can be concluded that respondents like reading reviews with positive values at Femaledaily.com. This proves that a trusted source will affect respondents in reading the reviews.

Although 3 independent variables affect Source of Trustworthiness, the same thing did not apply to EWOM Credibility. Authority has a positive effect on EWOM Credibility because consumers who feel that the information will impact them will think that the review is credible enough. Homophily and Interestingness has no positive effect, while Authority has a positive effect on EWOM Credibility. This happens because although consumers shared the same characteristics, they didn't think that EWOM that consumers deliver are credible enough. Consumers must make sure that EWOM is sourced from trusted people and credible. Three independent variables will have a greater relationship if the relationship was mediated by Source of Trustworthiness.

Source of Trustworthiness affects EWOM Credibility positively. This is because Femaledaily.com as an independent website has curated reviews based on specific type such as skin type and age. This specific detail will be seen as trusted source and it results in increasing credibility of the review. EWOM Credibility also has a significant relationship to Purchase Intention. The credibility of an independent website will be seen as a trusted source for readers.

\section{Conclusions and Suggestions}

Homophily, authority, and interestingness have a positive and significant influence on source of trustworthiness for personal-care product reviews on Femaledaily.com. Homophily and interestingness do not have a positive and insignificant impact on EWOM credibility. Meanwhile, the results of the study found that the authority had a positive and significant influence on EWOM credibility. The importance of three independent variables on source of trustworthiness has different results compared to the effect of the three variables on EWOM credibility. This proves that homophily, authority, and interestingness can have a positive impact on EWOM credibility. This happens because recipients or consumers will see the source of reviews before determining the level of credibility of EWOM.

Source of trustworthiness has a positive influence on EWOM credibility for Femaledaily.com. This means that if a trusted source delivers a review, then he or she has a high level of credibility. EWOM Credibility has a positive and significant influence on purchase intention. This is because EWOM's source on the Femaledaily.com website has high integrity, which influences consumers' motivation to purchase personal care products. Companies and brands need to pay attention to variables that have a strong relationship with the source of trustworthiness. Although homophily does not affect EWOM credibility, homophily can strengthen the source of trustworthinesss. Based on the results, it can be concluded that respondents feel Femaledaily.com is a website that is following their interests. Respondents also feel interested in exchanging ideas with people in this community. Companies need to focus on respondents at Femaledaily.com who have the same characteristics as their target consumers and learn about their behavior. This can be done by monitoring consumer activity on the website Femaledaily.com. 
Authority has a significant relationship to EWOM credibility, so companies or brands need to pay attention to the perceptions of consumers who have experience related to their products. Various indicators can increase EWOM credibility. The signs include: 1) Recommendations on Femaledaily.com often make me try personal care products, 2) Products that have been reviewed by Femaledaily.com motivated me to try them. The recommendations given by Femaledaily.com are collected based on the highest rating value and the number of comments on the product. Consumers who offer suggestions are considered to be people who have no affiliation with brands or companies, which builds the perception that they are credible reviews. In the future, brands that get recommendations from Femaledaily.com need to use Femaledaily.com recommendations to increase the product value of the company's brand so that consumers' perceptions rise. This is to show that products that have received endorsements from Femaledaily.com are products that have good quality and are trusted by consumers. Interestingness has a significant relationship to source of trustworthiness. This can be seen from the results of the research in which respondents prefer to read reviews that have a positive rating on Femaledaily.com. These results prove that a reliable source of information will make the respondent interested in reading reviews and finding out about the product. In the future, the highest rating brand from Femaledaily.com. can use it as content for the promotion of their products.

Consumers have a perception that the Femaledaily.com website is trusted and highly credible. This is because the website has acted as a neutral moderator and provides review features so that consumers can provide reviews regarding personal care product experiences. In the future, companies or brands can work with Femaledaily.com to build brand exposure levels for consumers in terms of video content creation. Video content was chosen because according to the results of the study, respondents often read reviews in the form of video content from Femaledaily.com. Brands and Femaledaily.com can package video content in such a way and attractive by working with leading and inspiring Beauty-Influencers or female figures.

Authority is a variable that has a positive effect on the Source of Trustworthiness. The relationship of these two variables is reinforced by indicators that state that recommendations and reviews from Femaledaily.com can motivate respondents to try personal care products. So, it can be concluded that consumers will believe if the reports from Femaledaily.com can have an impact on their lives because they get information from trusted Femaledaily.com sources. Personal care product brands need to monitor the activities of Femaledaily.com members who are considered capable of influencing others to try the product. The brand can invite members to collaborate on content promotion.

The credibility of the review significantly affects purchase intention from consumers. This credibility comes from trusted members who are active in writing reviews. In the future, Femaledaily.com and brands can work together to motivate members to write actively. Femaledaily.com along with Brand thanks members with a gift if members have written reviews.

\section{Limitations and future directions}

This study analyzes the factors that influence Femaledaily.com as a trusted website so that it can influence consumers to buy personal care products. Further research can continue to compare the effects of key opinion leaders with similar websites to see which aspect influences consumers to purchase most. Further studies can use male consumers as respondents in comparison with female consumers to analyze consumer behavior. This research is limited to general reviews on Femaledaily.com. In the future, research can be conducted on discussions that use a negative or positive tone of word-of-mouth on Femaledaily.com. 


\section{References}

Beneke, J., de Sousa, S., Mbuyu, M., \& Wickham, B. (2016). The effect of negative online customer reviews on brand equity and purchase intention of consumer electronics in South Africa. The International Review of Retail, Distribution and Consumer Research, 26(2), 171-201. https://doi.org/10.1080/09593969.2015.1068828

Campbell, J. M., \& Fairhurst, A. E. (2016). Reducing the intention-to-behaviour gap for locally produced foods purchasing: the role of store, trust, and price. International Journal of Retail \& Distribution Management, 44(5), 508523. https://doi.org/10.1108/IJRDM-08-2015-0121

Chakraborty, U., \& Bhat, S. (2018). Credibility of online reviews and its impact on brand image. Management Research Review, 41(1), 148-164. https://doi.org/10.1108/MRR-06-2017-0173

Gunawan, D. D., \& Huarng, K. H. (2015). Viral effects of social network and media on consumers' purchase intention. Journal of Business Research, 68(11), 2237-2241. https://doi.org/10.1016/j.jbusres.2015.06.004

Hidayanto, A. N., Ovirza, M., Anggia, P., Budi, N. F. A., \& Phusavat, K. (2017). The roles of electronic word of mouth and information searching in the promotion of a new e-commerce strategy: a case of online group buying in Indonesia. Journal of theoretical and applied electronic commerce research, 12(3), 69-85. https://doi.org/10.4067/S071818762017000300006

Hu, Y., \& Kim, H. J. (2018). Positive and negative eWOM motivations and hotel customers' eWOM behavior: Does personality matter? International Journal of Hospitality Management, 75, 27-37. https://doi.org/10.1016/j.ijhm.2018.03.004

Hussain, S., Ahmed, W., Jafar, R. M. S., Rabnawaz, A., \& Jianzhou, Y. (2017). eWOM source credibility, perceived risk and food product customer's information adoption. Computers in Human Behavior, 66, 96-102. https://doi.org/10.1016/j.chb.2016.09.034

Industry, B. (2017). E PORT. Jakarta.

Jafar, A., Adidam, P. T., \& Prasad, M. V. R. (2011). Celebrity endorsements vis-a-vis brand equity of high fashion products: A cross-cultural perspective. Innovative Marketing, 7(4), 72-80.

Kim, H., \& Hanssens, D. M. (2017). Advertising and word-of-mouth effects on pre-launch consumer interest and initial sales of experience products. Journal of Interactive Marketing, 37, 57-74. https://doi.org/10.1016/j.intmar.2016.08.001

Martins, J., Costa, C., Oliveira, T., Gonçalves, R., \& Branco, F. (2019). How smartphone advertising influences consumers' purchase intention. Journal of Business Research, 94, 378-387. https://doi.org/10.1016/j.jbusres.2017.12.047

Ministry of Trade. (2017). Indonesia: Personal Care \& Cosmetics Products.

Moslehpour, M., Wong, W. K., Pham, K. V., \& Aulia, C. K. (2017). Repurchase intention of Korean beauty products among Taiwanese consumers. Asia Pacific Journal of Marketing and Logistics, 29(3), 569-588. https://doi.org/10.1108/APJML-06-2016-0106

Pauwels, K., Aksehirli, Z., \& Lackman, A. (2016). Like the ad or the brand? Marketing stimulates different electronic word-of-mouth content to drive online and offline performance. International Journal of Research in Marketing, 33(3), 639-655. https://doi.org/10.1016/j.ijresmar.2016.01.005

Reimer, T., \& Benkenstein, M. (2018). Not just for the recommender: How eWOM incentives influence the recommendation audience. Journal of Business Research, 86, 11-21. https://doi.org/10.1016/j.jbusres.2018.01.041

Shamhuyenhanzva, R. M., Van Tonder, E., Roberts-Lombard, M., \& Hemsworth, D. (2016). Factors influencing Generation Y consumers' perceptions of eWOM credibility: a study of the fast-food industry. The International Review of Retail, Distribution and Consumer Research, 26(4), 435-455.https://doi.org/10.1080/09593969.2016.1170065

Shang, S. S., Wu, Y. L., \& Sie, Y. J. (2017). Generating consumer resonance for purchase intention on social network sites. Computers in Human Behavior, 69, 18-28. https://doi.org/10.1016/j.chb.2016.12.014

Shang, S. S., Wu, Y. L., \& Li, E. Y. (2017). Field effects of social media platforms on information-sharing continuance: Do reach and richness matter?. Information \& Management, 54(2), 241-255. https://doi.org/10.1016/j.im.2016.06.008

Shang, S. S., Wu, Y. L., \& Sie, Y. J. (2017). Generating consumer resonance for purchase intention on social network sites. Computers in Human Behavior, 69, 18-28. https://doi.org/10.1016/j.chb.2016.12.014

Tien, D. H., Rivas, A. A. A., \& Liao, Y. K. (2018). Examining the influence of customer-to-customer electronic wordof-mouth on purchase intention in social networking sites. Asia Pacific Management Review. https://doi.org/10.1016/j.apmrv.2018.06.003 
Vahdati, H., \& Mousavi Nejad, S. H. (2016). Brand Personality Toward Customer Purchase Intention: The Intermediate Role of Electronic Word-Of-Mouth and Brand Equity. Asian Academy of Management Journal, 21(2).: http://dx.doi.org/10.21315/aamj2016.21.2.1

VanMeter, R., Syrdal, H. A., Powell-Mantel, S., Grisaffe, D. B., \& Nesson, E. T. (2018). Don't just “Like” me, promote me: How attachment and attitude influence brand related behaviors on social media. Journal of Interactive Marketing, 43, 83-97. https://doi.org/10.1016/j.intmar.2018.03.003

Wardani, A. K., \& Rumyeni, R. (2017). The Influence of Electronic Word of Mouth on the Female Daily Online Forum Against Interest in Buying Purbasari Products among Young Women. Online Journal of Social and Political Sciences Faculty of Riau University Students, 4 (2), 1-15. https://www.neliti.com/publications/131635/pengaruh-electronicword-of-mouth-pada-forum-online-female-daily-terhadap-minat

Yang, Y., Park, S., \& Hu, X. (2018). Electronic word of mouth and hotel performance: A meta-analysis. Tourism management, 67, 248-260. https://doi.org/10.1016/j.tourman.2018.01.015 